\title{
Feeding of Eigenmannia trilineata (Pisces, Sternopygidae) (Lopez \& Castello, 1966), in the upper Paraná River floodplain, Brazil.
}

\author{
Danielle Peretti and Izabel de Fátima Andrian* \\ Department of Biology, Nupélia, Universidade Estadual de Maringá, Av. Colombo, 5790 - 87020-900 - Maringá, \\ Paraná, Brazil.
}

\begin{abstract}
Studies were performed on various aspects related to the feeding of Eigenmannia trilineata in the upper Paraná River floodplain, from June 1993 to July 1994, at four places with different types of bottom and waters speed. A number of 279 fish had its stomachal contents analyzed by occurence and point methods in which it was applied on its frequencies the feeding index. Two hundred an sixty two specimens were utilized to the analysis of the feeding activity that it was based on frequency and middle degree of stomach repletion. For the morfological analyse utilized 12 individuals. It was verified fourteen items on species diet which it was found chiefly Chironomidae (Diptera) and detritus. Seasonal, area variations were verified in feeding activity and the participation of constituent items in diet. The results showed that the species presents nightly and benthophagous habits, with morfological characters of the carnivorous species.
\end{abstract}

Key words: feeding; Eigenmannia trilineata; Pisces; Paraná River.

\section{INTRODUCTION}

Floodplain constitute complex systems for the wealth of aquatic assemblies and intense interaction among its species and, still of those with the populations that occupy the varzea or the riparian ecotone, flooded periodically. Thus, it can be said that floodplains are areas that suffer accentuated modifications in its area and in the relationships among its inhabitants, due to the variations of the hydrologic level. In environment structured like this the diet and the alimentary rhythm of the fish can be highly influenced by modifications in availability food, as discussed by several authors (WELCOMME, 1979; JUNK, 1980; LOWE-McCONNELL，1987; MACHADO-ALLISON, 1990; BRAGA, 1990).

According to AGOSTINHO \& ZALEWSKI (1996) large - sized and commercially important species of fish of this plain used the floodplain environment and the channels of the rivers that composed the system during their life cycle. The authors emphazise that the lentic environments, besides their role as spawning areas for great number of forage species, were used by larger species for the juveniles development and recovery.

Among the species of Gymnotiformes studied in the plain (AGOSTINHO et al, 1997), Eigenmannia trilineata was considered a rare species in lotic environments and temporary ponds, sporadic species in lentic environments and moderated in streams. Such species, popularly known as espadinha or tuvira, has its economic importance back for the commercialization with the purpose of being used as bait, because it serves as food for another fish

The present describes the studies developed in the upper Paraná river floodplain area. Consequently, E. trilineata was studied, emphasizing the related feeding aspects, approaching the diet and the alimentary activity, analyzing the influence of environmental factors and inferring existent relationships between the morphology of the digestive tract and the feeding.

\footnotetext{
* Author for correspondence
} 


\section{MATERIAL AND METHODS}

The study area of the basin of the Paraná River is located among the coordinates $22^{\circ} 40^{\prime}$ -
$22^{0} 50^{\prime} \mathrm{S}$ and $53^{0} 15^{\prime}-53^{\circ} 40^{\prime} \mathrm{W}$ and belongs to the superior stretch of the river (MAACK, 1981; PAIVA, 1982).

Table 1. Characterization of the biotopes

\begin{tabular}{l|l|l|l}
\hline Biotopes & Bottom Type & Current Speed & Environment Characteristic \\
\hline Paraná River & Medium sand to thick & Overcome 1.4 m/s & Lotic \\
\hline Baia - Praia & $\begin{array}{l}\text { Rich mud in organic and sand } \\
\text { matter. }\end{array}$ & $0.499 \mathrm{~m} / \mathrm{s}$ & A blend of lotic and lentic environment \\
\hline Baia - Pedreira & $\begin{array}{l}\text { Rich mud in organic and pebbly } \\
\text { matter }\end{array}$ & $0.499 \mathrm{~m} / \mathrm{s}$ & A blend of lotic and lentic environment. \\
\hline Patos Lagoon & Organic matter in decomposition & - & Lentic \\
\hline
\end{tabular}

Extracted data from Souza Filho \& Stevaux (1997)

The collections were made from June 1993 to May 1994, with monthly periodicity and with two daily drags, at $12 \mathrm{pm}$ and $8 \mathrm{pm}$. Three drag nets with mesh of $0.8 \mathrm{~cm}$ in the sleeve and 0.5 $\mathrm{cm}$ in the sack were used for collections. The nets were thrown at the same time and picked up separately.

For the determination of the diet and verification of space and temporary variations, the occurrence methods and points were used, this last one with modification (HYNES, 1950; HYSLOP, 1980), and the alimentary index (KAWAKAMI \& VAZZOLER, 1980).

To the stomach the repletion degree was attributed (GR) in a scale of gastric emptying of: 0 - emptiness, 1 - with some food, 2 - partially full and 3 - full. In the analysis of the alimentary activity the medium repletion rate was used $(\mathrm{GRm})$. According to the formula, $\mathrm{GRm}=(0 \mathrm{n} 0$ $+1 \mathrm{n} 1+2 \mathrm{n} 2+3 \mathrm{n} 3) /(\mathrm{n} 0+\mathrm{n} 1+\mathrm{n} 2+\mathrm{n} 3)$, and the frequency of the repletion rate.

Besides the morphological description of the main structures related with the feeding, the intestinal coefficient, which is the ratio between the intestinal length and the standard length of the fish, was also calculated

\section{RESULTS AND DISCUSSION}

The studied copies varied between 3.7 to 17.8 $\mathrm{cm}$ of standard length. For the analysis of the stomach content of the individuals' of $E$. trilineata total, it was possible to verify that although the species presented fourteen alimentary categories, had as main Chironomidae (Diptera) and detritus, which, together reached about $80 \%$ of the ingested food (Table 2). This was common for many species of the plain, with different alimentary habits, as reported by ALMEIDA et al (1997) in piscivores; FERRETTI et al (1996) in herbivores and LOLIS \& ANDRIAN (1996) in omnivorous. The other categories, considered of less importance in the diet were, ingested simultaneously with the main ones (HONDA, 1972). Understood that this can be true if the main items are abundant and available for the fish.

Our results on alimentary spectrum of $E$. trilineata suggested the benthophagous habit of the species. FUGI et al (1996) differentiating detritivores and iliophagous discuss the alimentary habit in Iheringichthys labrosus and Trachydoras paraguayensis. The authors considered the benthophagous species as selectors of benthic organisms. As reported by TAKEDA et al (1997), Chironomidae was present in all environmental sets of the floodplain, with some abundant genus in every environments. 
Then, the fact of this species feeding on food, as well as its ability in exploring the bottom of the water bodies.

MARLIER (1968) and SOARES (1979) in their study on E. virescens found aquatic insects larvae and microcrustaceans as components of the diet. Similarly for Eigenmannia sp, GOULDING et al (1988) and FERREIRA (1984) verified the same items and this last author
Chironomidae can show the abundance of that classified the species as carnivorous. KNOPPEL (1970), MARRERO (1987) and LOWEMcCONNELL (1991) for the family Sternopygidae mentioned the same animal items and added detritus. This way, this group seemed not to present variations in the benthophagous habit, just changed the main animal groups of agreement probably with the availability in the environment.

Table 2. Composition of the diet of Eigenmannia trilineata, according to the Alimentary Index. 1=total of individuals; 2(drought), 3(transition) and 4(flood) = seasonal variation; 5(Baia-Praia), 6(Baia-Pedreira), 7(Patos Lagoon), 8(Paraná River) = space variation.

\begin{tabular}{|c|c|c|c|c|c|c|c|c|}
\hline & 1 & 2 & 3 & 4 & 5 & 6 & 7 & 8 \\
\hline & $n=279$ & $n=168$ & $n=89$ & $n=22$ & $\mathrm{n}=47$ & $n=53$ & $n=175$ & $n=4$ \\
\hline Alimentaries Items & \multicolumn{8}{|c|}{ Alimentary Index Percentage } \\
\hline Chironomidae & 47.13 & 45.86 & 49.39 & 38.41 & 48.59 & 60.44 & 34.23 & 57.06 \\
\hline Others Diptera & 0.28 & 0.01 & 1.39 & 0.19 & 1.01 & 0.84 & 0.01 & 1.98 \\
\hline Others insects & 1.59 & 0.17 & 5.66 & 4.49 & 6.31 & 1.69 & 0.80 & 14.13 \\
\hline Copepoda & 5.76 & 5.78 & 5.96 & 2.84 & 7.32 & 4.71 & 6.40 & 1.13 \\
\hline Ostracoda & 2.46 & 1.64 & 3.49 & 2.75 & 2.16 & 1.87 & 2.70 & 1.13 \\
\hline Cladocera & 0.37 & 0.27 & 0.26 & 2.48 & 2.34 & 0.02 & 0.40 & 0.85 \\
\hline Others crustaceans & 0.03 & - & - & 0.42 & - & 0.002 & 0.003 & - \\
\hline Acarina & 0.59 & 0.25 & 1.15 & 1.29 & 1.50 & 0.66 & 0.35 & 0.42 \\
\hline Arthropoda's eggs & 0.04 & 0.01 & 0.09 & 0.01 & 0.07 & 0.08 & 0.02 & - \\
\hline Nematoda & 0.02 & 0.01 & 0.05 & 0.24 & 0.15 & - & 0.02 & 0.14 \\
\hline Scales & 0.47 & 0.39 & 0.54 & 0.61 & 1.58 & 0.10 & 0.49 & 0.85 \\
\hline Seeds & 0.002 & - & - & 0.05 & - & - & - & 0.85 \\
\hline Detritus & 33.65 & 36.27 & 25.40 & 45.55 & 23.29 & 22.68 & 45.39 & 20.91 \\
\hline Sand & 7.62 & 9.34 & 6.63 & 0.68 & 5.68 & 6.90 & 9.18 & 0.56 \\
\hline Total & 100 & 100 & 100 & 100 & 100 & 100 & 100 & 100 \\
\hline
\end{tabular}

- absence of the item other insects ( Collembola, Trichoptera, Ephemeroptera, Homoptera and Coleoptera).

According to JUNK (1980), in these areas there were intimate relationship between the aquatic environment and the terrestrial, reflecting in the structure of the alimentary nets. The amount of food available to the fauna was constantly changing, and sometimes in extreme conditions, there were great differences in the alimentary offer forcing some organisms to adapt.

Analysis of the seasonal variation in the diet (Table 2), revealed that during low waters and transition periods, the most abundant item was Chironomidae, followed by item detritus. There was larger participation of other insects in the transition phase and flood. The totality of these insects is almost of autochthonous origin, as well as reported by KNOPPEL (1970) for
Sternopygidae and GOULDING et al (1988) for Eigenmannia sp. In the high waters period, unlike the others, detritus was evidenced as the main one, proceeded by Chironomidae. In studies of the benthonic fauna, TAKEDA et al (1997) claimed that the smallest densities of Chironomidae happened during the flood, especially in lentic environments. This fact possibly was due to the reproductive habits of this Diptera, being more abundant in its young phase during the periods of low waters and transition, when compared with the high waters. During this period shows the adults with less availability for the feeding of the fish, because in this phase of the life cycle are terrestrial. The organic matter in decomposition can be more abundant during the full, due to the increase of 
the area covered by the waters. Also, with larger dispersion of the organisms, due to the increase of shelters during the high waters, E. trilineata consumes larger amount of detritus.

Analyzing the space variation in the composition of the diet of the species (Table 2) it was verified that in the Baia river (Praia and Pedreira) and in the Paraná River biotopes Chironomidae appeared in larger proportion was Chironomidae, followed by detritus, however, in the Patos Lagoon. this was inverted and detritus reached larger proportion. This was due to the environment type, which was lentic with large accumulation of organic matter in decomposition. Other insects also showed variation with the environments, being more expressive in the Paraná River and Baia-Praia. Copepoda according to LANSAC-TÔHA et al (1997) were more abundant in lentic and a blend of lentic and lotic environments, however, they occured in everyone.

The benthic community reflected the environmental conditions well due to its great contact with the substratum. The species in study was important link in the alimentary detritus chain (BOWEN, 1983) It constituted the main flow of energy and cycling of materials. FUGI \& HAHN (1991) say that bottom feeders fish acted in the phase of previous mineralization of the organic matter of the mud, turning it easier of being decomposed by microorganism.

Absence of empty stomach was verified in the analyzed individuals, therefore the vacuity index for the species was zero (Table 3). For the individuals' of the plain total medium repletion rate was 1.84 , with frequencies of the rates of repletion 1,2 and 3 of $34.73,46.18$ and $19.08 \%$, respectively. The absence of empty stomach could be related to the benthophagous habit of the species. HAHN et al (1991), referring the species $T$. paraguayensis, made the verification of the high frequency of stomach with food and of the small oscillation of the medium repletion rate for the different shifts of the day and sampling stations, suggesting that the food ingestion should happen to short intervals of time, tends as explanation the reduced size of its preys. Of nineteen specimens of E. virescens, analyzed by SOARES (1979), just one didn't present content. The present study on 262 analyzed individuals, 258 were captured at 8 $\mathrm{pm}$, which portrayed larger movement of the species in search of food, if compared with the schedule of $12 \mathrm{pm}$, when just 4 specimens were collected, although these were also with content in their stomach.

Table 3. Frequencies and medium values of the repletion rate of Eigenmannia trilineata.

\begin{tabular}{c|c|c|c|c|c|c|c|c|c|c|c}
\hline \multirow{2}{*}{ VARIATIONS } & \multicolumn{2}{|c|}{ GR 0} & \multicolumn{2}{|c|}{ GR 1 } & \multicolumn{2}{c|}{ GR 2 } & \multicolumn{2}{c|}{ GR 3 } & \multicolumn{2}{c|}{ TOTAL } & \\
\cline { 2 - 14 } & $\mathrm{N}$ & $\%$ & $\mathrm{~N}$ & $\%$ & & $\%$ & $\mathrm{~N}$ & $\%$ & $\mathrm{~N}$ & $\%$ & GRm \\
\hline \hline Floodplain-Paraná River & 0 & 0.00 & 91 & 34.73 & 121 & 46.18 & 50 & 19.08 & 262 & 100 & 1.84 \\
\hline \hline $12 \mathrm{pm}$ & 0 & 0.00 & 1 & 25.00 & 3 & 75.00 & 0 & 0,00 & 4 & 100 & 1.75 \\
\hline $8 \mathrm{pm}$ & 0 & 0.00 & 90 & 34.88 & 118 & 45.74 & 50 & 19.38 & 258 & 100 & 1.84 \\
\hline \hline Drought & 0 & 0.00 & 51 & 33.77 & 69 & 45.69 & 31 & 20.53 & 151 & 100 & 1.87 \\
\hline Transition & 0 & 0.00 & 34 & 38.20 & 41 & 46.07 & 14 & 15.73 & 89 & 100 & 1.78 \\
\hline Flood & 0 & 0.00 & 6 & 27.27 & 11 & 50.00 & 5 & 22.73 & 22 & 100 & 1.95 \\
\hline Paraná River & 0 & 0.00 & 0 & 0.00 & 1 & 25.00 & 3 & 75.00 & 4 & 100 & 2.75 \\
\hline Baia-Praia & 0 & 0.00 & 14 & 29.79 & 24 & 51.06 & 9 & 19.15 & 47 & 100 & 1.89 \\
\hline Baia-Pedreira & 0 & 0.00 & 9 & 20.93 & 22 & 51.16 & 12 & 27.91 & 43 & 100 & 1.58 \\
\hline Patos Lagoon & 0 & 0.00 & 68 & 40.48 & 74 & 44.05 & 26 & 15.48 & 168 & 100 & 1.75 \\
\hline
\end{tabular}

The daily rhythms revealed adaptations of the species to the environment. MANTEIFEL et al biological interaction that resulted in daily rhythms of activity and feeding of the fish.
(1978), reported that the food availability and predators were important components of the BARTHEM (1987), in the study of circadians rhythms in fish showed that the capture 
frequency revealed the predominant behavior of each species, according to the nocturne concept and of the day and of transition, called of twilight. The schedules of larger capture represented the one of larger movement in search of refuge for the rest or in search of feeding place. The fact that almost all $E$. trilineata were captured at the $8 \mathrm{pm}$, twilight schedule - evening paper, revealed that this species adjusted in this type of behavior,, was believed that in the night period the species would be less susceptible to the predation, once its food was available during the 24 hours of the day, making the species able to have a continuous feeding or not.

Considering the variation in the alimentary activity, due to the hydrologic level (Table 2), it was verified that, although with small differences, it was during to flood that the stomach was fuller than the other periods. This was due to the fact of being in this period the largest detritus ingestion, that occupied larger volume in the stomach, once the attribution of GR gave the volume of the stomach. The absence of strong variations could partly be explained by the fact that the species did not migrate and to have available food in any phase of the hydrologic regime. FUGI et al (1996), studying five species bottom feeders in the plain of the upper Paraná River also reported small seasonal oscillations in the alimentary rhythm, but HAHN et al (1997), verified that Hoplosternum litttorale, benthophagous species present in ponds of the plain showed larger alimentary activity during the high waters.

With regard to space variation, bottom with sand and organic matter favored more alimentary activity than the one of bottom with pebble. Rocky bottom facilitated the capture of animal items, consequently with smaller detritus ingestion, even for the smallest abundance of these. As verified in the diet, the copies collected in the biotopes Baia-Pedreira had its diet with larger percentual of Chironomidae $(60.44 \%)$, what characterized it as more nutritious, allowing smaller alimentary activity. However, in every environments the species showed repletion rate above the medium value of 1.50, could be considered with high alimentary activity, own of the species with the benthophagous habit.
The frequency of the repletion rate (Table 3) besides the absence of GR 0, was in general, larger number of GR 2, followed by GR 1 and GR 3. These results suggested that the species could present rest intervals between a taking and another of food but, probably, didn't present interval between the end of the digestion and beginning of another ingestion period, in way the one that the stomach always comes with some content. This way, the ingestion and digestion of the alimentary content would last, at least 24 hours, being the ingestion begun in the twilight evening paper.

Due to multiplicity of factors that interfered in the diet, isolated interpretations of the composition of the related content the availability in the environment could take to incorrect ecological conclusions (BARBIERI $e t$ al, 1994). The authors demonstrated the importance of associating the diet to the morphological relationships of the digestive tract. The species E. trilineata presented terminal and small mouth, with disposition to protract, dependent of the mobility of the jaw. In agreement with WOOTTON (1990), this readiness could check advantages for obtaining of benthonics preys. ZAVALA-CAMIN (1996) mentioned that the function of the maxilla teeth was for holding the prey. In the studied species, it was believed that the pharyngeal teeth acts breaking the hardest parts of the insects, as well as triturating the detritus.

We found an average of six extremely short gill rakers with lobular form. Close to the arch there was a mucus's layer that served to the adhesion of alimentary particles, once the size and disposition of the rakers didn't allow the retention of the food, which was constituted of smaller items than the spacing among them. RUBENSTEIN \& KOCHL, (1977) mentioned that some species presented mucus in the rakers that increased the power of retention of smaller organisms.

The stomach occupies good part of the visceral cavity, which is small in relation with the proportions of the body. On average, the species had standard length of $12.7 \mathrm{~cm}$, the visceral cavity presented a length of just $1.8 \mathrm{~cm}$, while 
the stomach measured $1.2 \mathrm{~cm}$. The bag - like stomach presented in the pyloric portion two pairs of caeca, one shorter in relation to the other. According to ZAVALA-CAMIN (1996) and DRAKE et al (1984), the pyloric caeca possessed the same structure and function of the intestine, so, it increased the surface of this organ.

In twelve fish the medium intestinal coefficient was equal to 0.249 . In spite of the small sizeof the intestine, to be compatible with the visceral cavity which is also small, it had four folds. Short intestines are typical of carnivores, this way, nevertheless the high detritus ingestion for the species, the intestinal coefficient indicates that the animal items should be the main objective of the species, reinforcing the hypothesis presented above that, the detritus ingestion was more accidental than purposed. According to BARBIERI et al (1994), this coefficient was used as measure for the diagnosis and determination of the alimentary regime. It could be considered that the diet of $E$. trilineata was of high quality, could process the food with a smaller intestine than its total length, as said by WOOTTON (1990) that this happened with carnivores fish.

The analyses accomplished in this study allowed to characterize the species E. trilineata as benthophagous, with high alimentary activity, which tended as main food insects of the family Chironomidae (Diptera). Especially the lentic and a blend of lentic and lotic environment offered conditions for its development, being the alimentary behavior not very affected by the hydrologic regime.

\section{ACKNOWLEDGEMENTS}

The authors thank to $\mathrm{CNPq}$, for the concession of the scientific initiation scholarship; to the Department of Biology and the Nucleus of Researches in Limnology, Ichthyology and Aquaculture (Nupélia), for the logistic support.

\section{RESUMO}

Os estudos foram realizados sob vários aspectos relacionados à alimentação de Eigenmannia trilineata na planície de inundação do alto rio Paraná, de junho de 1993 a julho de 1994 em quatro locais com diferentes tipos de fundo e velocidade de águas. Um número de 279 peixes tiveram seus estômagos analisados pelos métodos de ocorrência e pontos sendo aplicado sobre suas frequências o índice alimentar. Duzentos e sessenta e dois indivíduos foram utilizados para a análise da atividade alimentar, a qual foi baseada sobre a frequiência e grau de repleção médio dos estômagos. Para a análise morfológica foram utilizados 12 indivíduos. Foi verificado 14 itens na dieta da espécie, encontrando-se principalmente Chironomidae (Diptera) e detritos. Variações sazonais e de área foram verificados na atividade alimentar e na participação dos itens constituintes da dieta. Os resultados mostraram que a espécie apresenta hábitos noturno e bentófago, com características morfológicas de espécies carnívoras.

\section{REFERENCES}

Agostinho, A A; Zalewski, M. (1996), A planície alagável do alto rio Paraná: importância e preservação. EDUEM, Maringá.

Agostinho, A. A.; Júlio Jr., H. F.; Gomes, L. C.; Bini, M. L.; Agostinho, C. S. (1997), Composição, abundância e distribuição espaço temporal da ictiofauna. In-A planície de inundação do alto rio Paraná: aspectos físicos, biológicos e socioeconômicos,ed.: EDUEM. Nupélia, pp. 179-208.

Almeida, V. L. L.; Hahn, N. S.; Vazzoler, A. E. A. (1997), Feeding patterns in five predatory fishes of the high Paraná River floodplain (PR, Brazil). Ecology of Freshwater Fisher, 6(3), 123-133.

Barbieri, G.; Peret, A. C.; Verani, J. R.(1994), Notas sobre a adaptação do trato digestivo ao regime alimentar em espécies de peixes da região de São Carlos (SP). I Quociente intestinal. Rev. Brasil. Biol., 54(1), 63-69.

Barthem, R. B. (1987), Uso de redes de espera no estudo de ritmos circadianos de algumas espécies de peixes nos lagos de várzea do rio 
Solimões. Revista Brasil. Zool., 3(7), 409422.

Bowen, S. H. (1983), Detritivory in neotropical fish communities. Environmental Biology of Fishes, 9(2), 137-144.

Braga, F. M. de S. (1990), Aspectos da reprodução e alimentação de peixes comuns em um trecho do rio Tocantins entre Imperatriz e Estreito, Estados do Maranhão e Tocantins, Brasil. Rev. Brasil. Biol., 50(3), 547-558.

Drake, P.; Arias, A. M.; Gallego, L. (1984), Biologia de los Mugilídeos ( Osteichthyes, Mugilidae ) en los esteros de las salinas de San Fernando ( Cádiz ). III. Hábitos alimentarios y su relación con la morfometría del aparato digestivo. Inv. Pesq., 48(2), 337-367.

Ferreira, E. J. G. (1984), A ictiofauna da represa hidrelétrica de Curuá-Una, Santarém, Pará. II- Alimentação e hábitos alimentares das principais espécies. Amazoniana, 9(1), 1-16.

Ferretti, C. M. L.; Andrian, I. F.; Torrente, G. (1996), Dieta de duas espécies de Schizodon (Characiformes, Anostomidae), na planície de inundação do alto rio Paraná e suas relações com aspectos morfológicos. $B$. Inst. Pesca, 23, 171-186.

Fugi, R.; Hahn, N. S. (1991), Espectro alimentar e relações morfológicas com o aparelho digestivo de três espécies de peixes comedoras de fundo do rio Paraná, Brasil. Rev. Brasil. Biol., 51(4), 873-879.

Fugi, R.; Hahn, N. S.; Agostinho, A. A. (1996), Feeding styles of five species of bottomfeeding fishes of the high Paraná River. Enviromental Biology of Fishes, 46, $297-$ 307.

Goulding, M.; Carvalho, M. L.; Ferreira, E. G. (1988), Rio Negro, rich life in poor water. SPB Academic Publish, The Hague, The Netherlands.

Hahn, N. S.; Almeida, V. L. L.; Luz, K. D. (1997), Alimentação e ciclo alimentar diário de Hoplosternum littorale (Hancock) (Siluriformes, Callichthyidae) nas lagoas Guaraná e Patos da planície do alto rio Paraná, Brasil. Revta. Bras. Zool., 14(1), 5764.

Hahn, N. S.; Fugi, R.; Andrian, I. F. (1991), Espectro e atividade alimentares do armadinho, Trachydoras paraguayensis ( Doradidae; Siluriformes ) em distintos ambientes do rio Paraná. Rev. Unimar, 13(2), 177-194.

Honda, E. M. S. (1972), Contribuição ao conhecimento da biologia de peixes do Amazonas. II. Alimentação do tambaqui, Colossoma bidens ( Spix ). Acta Amazônica, 4(2), 47-53.

Hynes, H. B. N. ( 1950), The food of fresh water sticklebacks (Gasterosteus aculeatus and Pygosteus pungitius ) with a review of methods used in studies of the food of fishes. J. Anim. Ecol., 19, 35-38.

Hyslop, E. J. (1980), Stomach contents analysis - a review of methods and their aplication. $J$. Fish. Biol., 17, 411-429.

Junk, W. J. (1980), Áreas inundáveis - um desafio para a limnologia. Acta Amazônica, 10(4), 775-796.

Kawakami, E.; Vazzoler, G. (1980), Método gráfico e estimativa de índice alimentar aplicado no estudo de alimentação de peixes. Bolm. Inst. Oceanogr., 29(2), 205-207.

Knöppel, H-A. (1970), Food of Central Amazonian fishes contribution to the nutrient-ecology of Amazonian rain-foreststreams. Amazoniana, 2(3), 257-352.

Lansac-Tôha, F. A.; Bonecker, C. C.; Velho, F. L. M.; Lima, A. F. (1997), Composição, distribuição e abundância da comunidade zooplanctônica. In-A planície de inundação do alto rio Paraná: aspectos físicos, biológicos e sócioeconômicos, ed. EDUEM. Nupélia, Maringá, pp. 117-156.

Lolis, A. A.; Andrian, I. F. (1996), Alimentação de Pimelodus maculatus Lacépè, 1803 (Siluriformes, Pimelodidae) na planície de inundação do alto rio Paraná, Brasil. B. Inst. Pesca, 23, 171-186.

Lowe-McConnell, R. H. (1987), Ecological studies in tropical fish communities. Cambridge University Press, Cambridge.

Lowe-McConnell, R. H. (1991), Natural history of fishes in Araguaia and Xingu Amazonian tributary, Serra do Roncador, Mato Grosso, Brazil. Ichthyol. Explor. Freshwaters, 2(1), 63-82.

Maack, R. (1981), Geografia física do estado do Paraná. J. Olympio, Rio de Janeiro.

Machado-Allisson, A. (1990), Ecologia de los peces de las areas inundables de los llanos de Venezuela. Interciência, 15(6), 411-423.

Manteifel, B. P.; Girsa, I. I.; Pavlov, D. S. (1978), On rhythms of fish behaviour. In.- 
Rhythmic activity of fishes, ed. Academic Press, London, pp. 215-224.

Marlier, G. (1968), Etude sur les lacs de l'Amazonie Central. Caderns Amazonia, 11, 21-57.

Marrero, C. (1987), Notas preliminares acerca de la historia natural de los peces del Bajo Llano. 1-Comparación de los hábitos alimentarios de tres especies de peces gymnotiformes en el Rio Apure (Edo Apure, Venezuela). Ver. Hydrobiol. Trop., 20(1), 57-63.

Paiva, M. P. (1982), Grandes represas do Brasil. Editerra, Brasília.

Rubenstein, D. I.; Koehl, M. A. R. (1977), The mechanisms of filter feeding: some theoretical considerations. Amer. Nat., 111(981), 981-994.

Soares, M. C. M. (1979) Aspectos ecológicos (alimentação e reprodução) dos peixes de igarapé do Porto, Aripuanã, MT. Acta Amazônica, 9(2), 325-352.
Souza Filho, E. E.; Stevaux, J. C. (1997), Geologia e geomorfologia do complexo rio Baía, Curutuba e Ivinheima. In-A planície de inundação do alto rio Paraná: aspectos físicos, biológicos e socioeconômicos, ed. EDUEM. Nupélia,Maringá, pp. 3-46.

Takeda, A. M.; Shimizu, G. Y.; Higuti, J. (1997), Variações espaço-temporais da comunidade zoobêntica. In- $A$ planície de inundação do alto rio Paraná: aspectos físicos, biológicos e socioeconômicos, EDUEM. Nupélia, Maringá,1997. pp. 157178.

Welcomme, R. L. (1979), Fisheries Ecology of Floodplain Rivers. Logman, London.

Wootton, R. J. (1990), Ecology of teleost fishes. Chapman and Hall, London.

Zavala-Camin, L. A. (1996), Introdução aos estudos sobre alimentação natural em peixes. EDUEM, Maringá. 